\title{
Synthesis of Anionic Surface Active Agents Containing Heterocyclic Moiety From Long Chain Fatty Alcohols
}

\author{
Magda.H.Abdellattif ${ }^{1 *}$, A.M.F.Eissa ${ }^{2}$, H.M.Mohamed ${ }^{3}$ \\ $1{ }^{*}$ Deanship of Scientific Research, Faculty of pharmacy, Taif university, KSA, magdah11uk@hotmail.com \\ 2 Chemistry Departments, Faculty of Science, Benha University, Egypt \\ 3- Chemistry Department, Faculty of Science, Taif University, KSA
}

\section{ABSTRACT}

A series of novel groups of anionic surface active agent were synthesized. Synthesis of these surfactants via the reaction of long chain fatty alcohols (octyl, decyl and dodecyl) with maleic anhydride to give monoester. The monoester chloride reacted with amino derivatives of heterocyclic rings followed by addition of NaHSO3 .The surface tension, interfacial tension; Kraft point, emulsifying and wetting power were evaluated. Stability to hydrolysis, biodegradability and biological activities were measured. A comparison studies between the chemical structures and the results were done.

\section{Indexing terms/Keywords}

Surfactants, monoester chloride, biodegradability and biological activities

\section{SUBJECT CLASSIFICATION}

Organic chemistry - Surfactant chemistry

\section{INTRODUCTION}

Anionic surfactants are very widely distributed throughout science, technology and everyday life. Examples which at once come to mind are the washing, wetting out of textile materials, the preparation of dispersion and emulsion, the application of agricultural and a wide variety of special uses, the number of which is continually increasing ${ }^{1}$.

Among anionic surfactants containing an aromatic structure element are alkyl benzene sulphonate accompanied by alky-naphthalene sulfonates ${ }^{2-5}$. In these compounds, hydrophilic sulfonic group is separated from long chain alkyl hydrophobe by single six member benzene or naphthalene rings. The structure analogues to the above ones may be surfactants containing five member heteroaromatic groups. It has been well established that various thiazole, imidazol, pyrazole, pyridine, pyrimidine and quinoline are of biological interest ${ }^{6-9}$. This encourage us to synthesis a novel groups of anionic surfactants containing those nucleus from long chain fatty alcohols (octyl, decyl, dodecyl alcohols ) hopping to possess good surface properties and expected to have biological activities.

\section{Experimental procedures}

\subsection{Chemicals}

Maleic anhydride, thionyl chloride, octyl alcohol, decyl alcohol, dodecyl alcohol were Merck (Darmstadt) products, 2amino thiazole, 2- amino imidazol,3-amino pyrazole, 2-amino pyridine,2-amino pyrimidine and 8- amino quinoline were obtained from Aldrich (Steinheim, Germany). All other chemicals (solvents) were of analytical grade. The water used was doubly distilled.

\subsection{Synthesis Procedures}

\subsection{I-synthesis of maleic acid monoester:}

It was prepared by refluxing a mixture of maleic anhydride ( 1.0 mole) with fatty alcohols ( 1.0 mole) octyl alcohol (a), decyl alcohol (b),dodecyl alcohol (c)in benzene for six hours, in the presence of sulphuric acid as catalyst. After cooling the reaction mixture was distilled with water to ensure removal of unreacted alcohols. Further purification was effected by fractional distillation under vacuum ${ }^{10}$.

\subsection{II- Synthesis of acyl chloride compounds:}

The acyl chloride was formed by refluxing of thionyl chloride with maleic acid monester in water bath at $65{ }^{\circ} \mathrm{C}$ for three hours. After cooling, petroleum ether was added and heated to remove excess of thionyl chloride. ${ }^{20}$

\subsection{III- Preparation of anionic compounds:}

acyl chloride which was prepared in previous step was reacted with 2- amino thiazole, 2- amino imidazol,3-amino pyrazole, 2-amino pyridine,2-amino pyrimidine and 8- amino quinoline in presence of benzene as solvent for three hours to give the compounds that react with sodium bisulfate to give anionic surfactants (9-14a-c).

\subsection{Characterization of the prepared surfactants}


The structures of the synthesized compounds were confirmed by infrared (IR) and nuclear magnetic resonance ( ${ }^{1} \mathrm{H}$ NMR). The qualitative infrared absorption spectra of the synthesized compounds were recorded on a Beckmon 4220 spectrophotometer. The HNMR spectra of the compounds under investigation have been recorded in deuterated chloroform $\left(\mathrm{CDCl}_{3}\right)$ and /or in (DMSO) as a solvent and tetramethyl silane (TMS) as an internal reference with $90 \mathrm{MHz}$ signal and 4.000 gauss magnetic field.

\subsection{Properties of the prepared surfactants}

\section{4.a Surface and interfacial tension}

Surface tension and interfacial tension measurements were carried out according to Findlay ${ }^{11}$ with a Krüss tensiometer for different concentration of the synthesized surfactants using platinum iridium ring at constant temperature $25^{\circ} \mathrm{C}$.Paraffin oil was used for the interfacial tension measurements.

\section{4.b Emulsifying power}

A $20-\mathrm{ml}$ amount of a different surfactant solution (0.1\%) was individually placed in a $100-\mathrm{ml}$ cylinder and then $20 \mathrm{ml}$ of the paraffin oil was added. The cylinder was shaken vigorously for $10 \mathrm{~min}$ and then allowed to settle. The time required to separate $18 \mathrm{ml}$ of pure surfactant solution was recorded and the experiment was repeated three times for each surfactant. The average separation time of the three experiments was taken as an indication of the emulsification power of each surfactant ${ }^{12}$.

\section{4.c Stability to hydrolysis}

A mixture of $10 \mathrm{ml}$. of surfactant and $10 \mathrm{ml}$ of $2 \mathrm{~N}$ sulphuric acid or $\quad 0.05 \mathrm{~N} \mathrm{NaOH}$ were placed in a thermostat at $40^{\circ} \mathrm{C}$. The time it takes for a sample solution to be clouded as the result of hydrolysis shows the stability of the surfactant to hydrolysis ${ }^{13}$.

\section{4.d Wetting properties}

It was examind by standard Draves method ${ }^{14}$

\section{4.e Kraft point}

The temperature at which $1 \%$ solution becomes clear on gradual heating gives a convenient measure of aqueous solubility $^{12}$.

\section{4.f Biodegradability\%}

Die-awy method using river water samples taken daily, or even more frequently, were filtered through No. 1 Whatman filter paper before measuring the surface tension ${ }^{15}$ Measurements were periodically (each day) on each sample during the degradation test. Biodegradation percent (D) was calculated from 'the following law.

$$
D=\frac{\varphi_{t}-\varphi_{0}}{\varphi_{b t}-\varphi_{0}} \times 100
$$

where :

$$
\begin{aligned}
& \varphi_{t}=\text { surface tension at time } \mathrm{t} \\
& \varphi_{0}=\text { surface tension at time zero (the initial surface tension) } \\
& \varphi_{b t}=\text { surface tension of the blank experiment at time } \mathrm{t} \text { (i.e without the sample). }
\end{aligned}
$$

\section{Result and discussion}

The synthetic route of these surfactants was listed in scheme1.The structure of prepared surfactants were confirmed by IR and ${ }^{1} \mathrm{HNMR}$ as shown in table (1).

\subsection{Surface active properties and related properties:}

The surface active properties and related properties, including surface and interfacial tension, kraft point, foam height, emulsion stability, wetting time and stability to hydrolysis were investigated to evaluate the possible application of these products in different industrial fields. The surface activity and related properties of the synthesized compounds are given in Table (2).

\subsection{Surface and interfacial tensions:}


The surface and interfacial tension of the prepared surfactants are given in Table (2). It showed that, the prepared anionic surfactants have good surface properties while they have a strong effect on the value of surface and interfacial tension. This result indicates that these
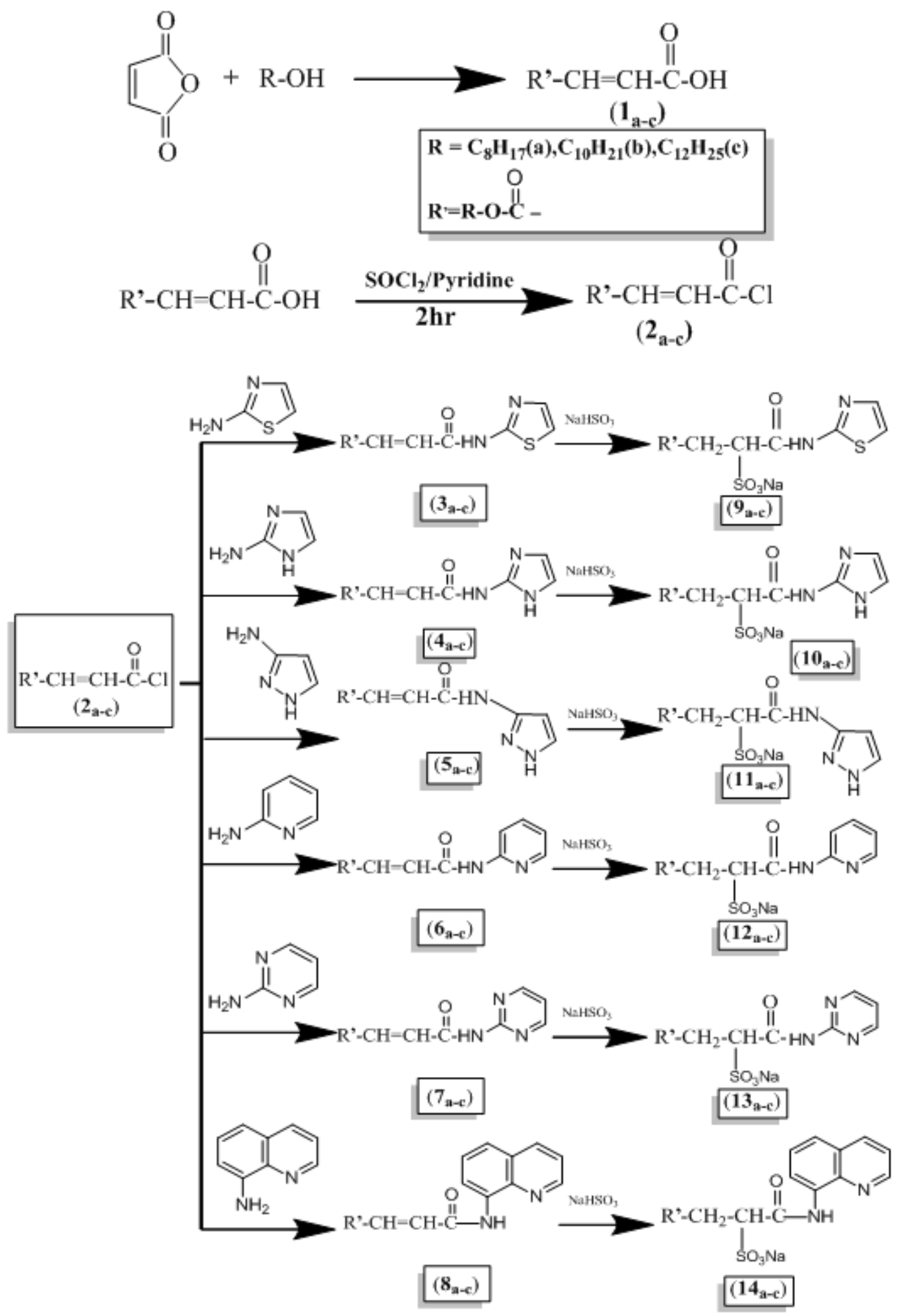

Scheme (1) synthesis of heterocyclic anionic surfactants

Compounds have a good surface activity. The results show that the surface tension decreases with increasing the alkyl chain length ${ }^{16}$. 


\subsection{Kraft point:}

The kraft point for the anionic synthesized surfactants which are freely soluble in water at 1 wt \% concentration is ranged between 16 and $13{ }^{\circ} \mathrm{C}$. While the compounds showed the lowest kraft points that may be attributed to the have the shorter fatty chain length ${ }^{17}$.

\subsection{Emulsion stability:}

The process of emulsification is the dispersion or suspension of fine particles of one liquid in another immiscible liquid. The emulsifying efficiency of a surfactant was related to the polarity of the molecule or the relation between the contribution of the polar hydrophilic head and the non polar lipophilic tail. From the data recorded in Table (2) the emulsifying properties increased with increasing the alkyl chain length of the fatty acid ${ }^{12}$. In fact the results of emulsification have good values which make them used in different industrial applications.

\subsection{Wetting time:}

The wetting properties of $1.0 \%$ solutions in distilled water were measured. The case with which the surface can be wetted by water as other liquids is an important properity suitable for many applications. Wetting powers obtained for the prepared sulfonamide surfactants are listed in Table (2). These compounds showed a good performance in wetting power. The wetting time slightly increases with increasing the chain length ${ }^{18}$.

\subsection{Stability to hydrolysis:}

All the prepared surfactants showed resistance to hydrolysis, probably because the adjacent sulpho group protects the amide linkage through steric hindrance ${ }^{13}$.these results make them stable in acidic and basic medium.From the measuring of the surface properties of the prepared compounds, we can notice that the change in the heterocyclic moiety have a little or no effect on this properties.

\subsection{Biodegradability}

A biodegradation test in ordinary river water ${ }^{15}$ gave good or excellent results table (3). The results of biodegradation reflect the fact that the biodegradability decreases with increasing the length of saturated aliphatic chain, which make the prepared anionic surfactants environmentally favorable. ${ }^{21}$

\subsection{Biological activity}

Biological activity of the synthesized compounds was reported that amino derivatives have a potential at the pharmacological level, so the antimicrobial activity of some new synthesized compounds was determined in vitro in the Botany Department, Faculty of Science, Benha University, Egypt. With the aim of obtaining specific derivatives that could be potent in medicine, chemistry or agriculture. A variety of species of G-positive bacteria (Bacillus megathorium) and Gnegative bacteria (Escherichia coli) in addition to some fungal plant pathogens (Mucor Species and Aspergillus flavus) were used, using a modified Kirby- Bauer disc diffusion method ${ }^{19}$.

In every case the minimum inhibitory concentration (MIC, $\mu \mathrm{g} / \mathrm{ml}$ ) was determined as the lower concentration of the compounds under study, which inhibits bacterial and fungal growth and the results are given in table (4).

It is apparent from the data, that most of the tested compounds have moderate to high activity against micro-ganisms. However, concerning the activity against G-positive bacteria (Bacillus megathorium).

\section{Table (1) the IR \& ${ }^{1} H N M R$ spectra of the anionic surfactants}

\begin{tabular}{|c|c|c|}
\hline Compound & $I R \mathrm{~cm}^{-1}$ & ${ }^{1} \mathrm{HNMR} \delta \mathrm{ppm}$ \\
\hline $99_{a}$ & $\begin{array}{c}\left(1306 \mathrm{~cm}^{-1} \mathrm{SO}_{3}\right),\left(1690 \mathrm{~cm}^{-1} \mathrm{C}=\mathrm{O} \text { of amide }\right) \text {, } \\
\left(1738 \mathrm{~cm}^{-1} \mathrm{C}=\mathrm{O} \text { of ester }\right),\left(2940 \mathrm{~cm}^{-1} \mathrm{C}-\mathrm{H}\right. \\
\text { aliphatic), }\left(3010 \mathrm{~cm}^{-1} \mathrm{C}-\mathrm{H} \text { aromatic }\right) \&(2600- \\
\left.3450 \mathrm{~cm}^{-1} \text { broad } \mathrm{NH}_{2}, \mathrm{NH} \& \mathrm{OH}\right)\end{array}$ & $\begin{array}{c}\left.\text { 0.82(t,term. } \mathrm{CH}_{3}\right), 1.2(\mathrm{~m}, 14 \mathrm{H} \text { of } \\
\left.\left(\mathrm{CH}_{2}\right)_{7}\right), 2.5\left(\mathrm{t}, \mathrm{CH}-\mathrm{SO}_{3} \mathrm{Na}\right), 2.9\left(\mathrm{~d}, \mathrm{CH}_{2}-\mathrm{CH}-\right. \\
\left.\mathrm{SO}_{3} \mathrm{Na}\right), 3.75\left(\mathrm{t}, 2 \mathrm{H}, \mathrm{CH}_{2}-\mathrm{O}\right), 4.9 \text { (br.s } \\
1 \mathrm{H}, \mathrm{NH}-), 7.6(\mathrm{~m}, 2 \mathrm{H} \text {,aromatic proton) }\end{array}$ \\
\hline $12_{b}$ & $\begin{array}{c}\left.\text { (1303 } \mathrm{cm}^{-1} \mathrm{SO}_{3}\right),\left(1692 \mathrm{~cm}^{-1} \mathrm{C}=\mathrm{O} \text { of amide }\right), \\
\left(1735 \mathrm{~cm}^{-1} \mathrm{C}=\mathrm{O} \text { of ester }\right),\left(2920 \mathrm{~cm}^{-1} \mathrm{C}-\mathrm{H}\right. \\
\text { aliphatic), }\left(3030 \mathrm{~cm}^{-1} \mathrm{C}-\mathrm{H} \text { aromatic }\right) \&(2580- \\
\left.3450 \mathrm{~cm}^{-1} \text { broad } \mathrm{NH}_{2}, \mathrm{NH} \& \mathrm{OH}\right)\end{array}$ & $\begin{array}{c}0.8\left(\mathrm{t}, \text { term. } \mathrm{CH}_{3}\right), 1.1-1.3(\mathrm{~m}, 18 \mathrm{H} \text { of } \\
\left.\left(\mathrm{CH}_{2}\right) 9\right), 2.4\left(\mathrm{t}, \mathrm{CH}_{-} \mathrm{SO}_{3} \mathrm{Na}\right), 2.9\left(\mathrm{~d}, \mathrm{CH}_{2}-\mathrm{CH}-\right. \\
\left.\mathrm{SO}_{3} \mathrm{Na}\right), 3.9\left(\mathrm{t}, 2 \mathrm{H}, \mathrm{CH}_{2}-\mathrm{O}\right), 4.9(\text { br.s, } 1 \mathrm{H}, \mathrm{NH}- \\
\text { ), 7.3-8.0(m,4H,aromatic proton })\end{array}$ \\
\hline $14_{c}$ & $\begin{array}{c}\left(1310 \mathrm{~cm}^{-1} \mathrm{SO}_{3}\right),\left(1697 \mathrm{~cm}^{-1} \mathrm{C}=\mathrm{O} \text { of amide }\right), \\
\left(1739 \mathrm{~cm}^{-1} \mathrm{C}=\mathrm{O} \text { of ester }\right),\left(2932 \mathrm{~cm}^{-1} \mathrm{C}-\mathrm{H}\right. \\
\text { aliphatic), }\left(3045 \mathrm{~cm}^{-1} \mathrm{C}-\mathrm{H} \text { aromatic }\right) \&(2600- \\
\left.3460 \mathrm{~cm}^{-1} \text { broad } \mathrm{NH}_{2}, \mathrm{NH} \& \mathrm{OH}\right)\end{array}$ & $\begin{array}{c}0.9\left(\mathrm{t}, \text { term. } \mathrm{CH}_{3}\right), 1.4(\mathrm{~m}, 22 \mathrm{H} \text { of } \\
\left.\left(\mathrm{CH}_{2}\right){ }_{11}\right), 2.5\left(\mathrm{t}, \mathrm{CH}-\mathrm{SO}_{3} \mathrm{Na}\right), 2.9\left(\mathrm{~d}, \mathrm{CH}_{2}-\mathrm{CH}-\right. \\
\left.\mathrm{SO}_{3} \mathrm{Na}\right), 3.8\left(\mathrm{t}, 2 \mathrm{H}, \mathrm{CH}_{2}-\mathrm{O}\right), 4.7(\mathrm{br} . \mathrm{s}, 1 \mathrm{H}, \mathrm{NH}- \\
), 7.3-8.0(\mathrm{~m}, 6 \mathrm{H}, \text { aromatic proton })\end{array}$ \\
\hline
\end{tabular}

Table (2) surface properties of the anionic surfactants 


\begin{tabular}{|c|c|c|c|c|c|c|c|c|c|}
\hline N0. & Structure & Mol. F & $\begin{array}{c}\text { Mol. } \\
\text { Wt }\end{array}$ & $\begin{array}{c}\text { S.T } \\
\text { Dyne/ } \\
\text { cm } \\
0.1 \%\end{array}$ & $\begin{array}{c}\text { I.T } \\
\text { Dyne/ } \\
\text { cm } \\
0.1 \%\end{array}$ & $\begin{array}{c}\text { K.P } \\
1 \\
\text { wt\% } \\
{ }^{\circ} \mathrm{C}\end{array}$ & $\begin{array}{c}\text { Stability } \\
\text { to } \\
\text { Hydroly } \\
\text { sis } \\
\text { min : } \\
\text { sec }\end{array}$ & $\begin{array}{c}\text { Wetti } \\
\text { ng } \\
\text { powe } \\
r \\
\text { Sec }\end{array}$ & $\begin{array}{c}\text { Emulsific } \\
\text { ation } \\
\text { Power } \\
\text { min : Sec }\end{array}$ \\
\hline $9_{a}$ & & $\begin{array}{c}\mathrm{C}_{15} \mathrm{H}_{25} \mathrm{O}_{6} \mathrm{~N}_{2} \mathrm{~S}_{2} \\
\mathrm{Na}\end{array}$ & 449.5 & 29 & 6.5 & 13 & $18: 40$ & 110 & $173: 13$ \\
\hline $9_{b}$ & & $\begin{array}{c}\mathrm{C}_{17} \mathrm{H}_{29} \mathrm{O}_{6} \mathrm{~N}_{2} \mathrm{~S}_{2} \\
\mathrm{Na}\end{array}$ & 477.5 & 33 & 8 & 15 & $18: 45$ & 143 & $187: 10$ \\
\hline $9 \mathrm{c}$ & & $\begin{array}{c}\mathrm{C}_{19} \mathrm{H}_{33} \mathrm{O}_{6} \mathrm{~N}_{2} \mathrm{~S}_{2} \\
\mathrm{Na}\end{array}$ & 505.5 & 35 & 9 & 16.5 & 19:55 & 153 & 190:06 \\
\hline $10_{a}$ & & $\begin{array}{c}\mathrm{C}_{15} \mathrm{H}_{23} \mathrm{O}_{6} \mathrm{~N}_{3} \mathrm{SN} \\
\mathrm{a}\end{array}$ & 396.5 & 34 & 8 & 14 & $20: 30$ & 149 & 194:17 \\
\hline $10_{b}$ & & $\begin{array}{c}\mathrm{C}_{17} \mathrm{H}_{27} \mathrm{O}_{6} \mathrm{~N}_{3} \mathrm{SN} \\
\mathrm{a}\end{array}$ & 424.5 & 37 & 8.5 & 17 & $23: 34$ & 160 & $230: 16$ \\
\hline $10_{c}$ & & $\begin{array}{c}\mathrm{C}_{19} \mathrm{H}_{31} \mathrm{O}_{6} \mathrm{~N}_{3} \mathrm{SN} \\
\mathrm{a}\end{array}$ & 452.5 & 39 & 9 & 19 & $20: 55$ & 189 & $240: 15$ \\
\hline $11_{a}$ & & $\begin{array}{c}\mathrm{C}_{15} \mathrm{H}_{23} \mathrm{O}_{6} \mathrm{~N}_{3} \mathrm{SN} \\
\mathrm{a}\end{array}$ & 396.5 & 36 & 7 & 16 & 19:34 & 190 & $235: 22$ \\
\hline $11_{b}$ & & $\begin{array}{c}\mathrm{C}_{17} \mathrm{H}_{27} \mathrm{O}_{6} \mathrm{~N}_{3} \mathrm{SN} \\
\mathrm{a}\end{array}$ & 424.5 & 34 & 8.5 & 17 & $22: 34$ & 210 & $254: 36$ \\
\hline $11_{c}$ & & $\begin{array}{c}\mathrm{C}_{19} \mathrm{H}_{31} \mathrm{O}_{6} \mathrm{~N}_{3} \mathrm{SN} \\
\mathrm{a}\end{array}$ & 452.5 & 39 & 10.5 & 19 & 24:05 & 231 & $266: 37$ \\
\hline $12 a$ & & $\begin{array}{c}\mathrm{C}_{17} \mathrm{H}_{26} \mathrm{O}_{6} \mathrm{~N}_{2} \mathrm{SN} \\
\mathrm{a}\end{array}$ & 409.5 & 35.5 & 8.5 & 13 & $23: 54$ & 210 & $251: 40$ \\
\hline
\end{tabular}




\begin{tabular}{|c|c|c|c|c|c|c|c|c|}
\hline $12_{b}$ & $\begin{array}{c}\mathrm{C}_{19} \mathrm{H}_{30} \mathrm{O}_{6} \mathrm{~N}_{2} \mathrm{SN} \\
\mathrm{a}\end{array}$ & 437.5 & 36 & 8.9 & 16 & $24: 36$ & 234 & $262: 13$ \\
\hline $12_{c}$ & $\begin{array}{c}\mathrm{C}_{21} \mathrm{H}_{34} \mathrm{O}_{6} \mathrm{~N}_{2} \mathrm{SN} \\
\mathrm{a}\end{array}$ & 465.5 & 39 & 8.911 & 18 & $26: 54$ & 255 & $277: 22$ \\
\hline $13_{a}$ & $\begin{array}{c}\mathrm{C}_{16} \mathrm{H}_{24} \mathrm{O}_{6} \mathrm{~N}_{3} \mathrm{SN} \\
\mathrm{a}\end{array}$ & 409.5 & 34.5 & 7 & 17 & $21: 43$ & 195 & $249: 34$ \\
\hline $13_{b}$ & $\begin{array}{c}\mathrm{C}_{18} \mathrm{H}_{28} \mathrm{O}_{6} \mathrm{~N}_{3} \mathrm{SN} \\
\mathrm{a}\end{array}$ & 437.5 & 39 & 11 & 17.5 & $26: 38$ & 260 & $288: 44$ \\
\hline $13_{c}$ & $\begin{array}{c}\mathrm{C}_{20} \mathrm{H}_{32} \mathrm{O}_{6} \mathrm{~N}_{3} \mathrm{SN} \\
\mathrm{a}\end{array}$ & 465.5 & 42 & 12.5 & 19 & $27: 57$ & 276 & $311: 15$ \\
\hline $14_{a}$ & $\begin{array}{c}\mathrm{C}_{21} \mathrm{H}_{27} \mathrm{O}_{6} \mathrm{~N}_{2} \mathrm{SN} \\
\mathrm{a}\end{array}$ & 482.5 & 33 & 8 & 15 & $29: 54$ & 267 & $245: 09$ \\
\hline $14_{b}$ & $\begin{array}{c}\mathrm{C}_{23} \mathrm{H}_{31} \mathrm{O}_{6} \mathrm{~N}_{2} \mathrm{SN} \\
\mathrm{a}\end{array}$ & 510.5 & 40 & 12 & 19 & $31: 34$ & 290 & 279:50 \\
\hline $14_{c}$ & $\begin{array}{c}\mathrm{C}_{25} \mathrm{H}_{35} \mathrm{O}_{6} \mathrm{~N}_{2} \mathrm{SN} \\
\mathrm{a}\end{array}$ & 538.5 & 45 & 13 & 20 & $38: 56$ & 333 & $343: 32$ \\
\hline
\end{tabular}

Table (3) Biodegradbility percent of prepared anionic surfactants

\begin{tabular}{|c|c|c|c|c|c|c|c|c|}
\hline Surfactant & $\mathbf{1}^{\text {st }}$ day & $\mathbf{2}^{\text {nd }}$ day & $\mathbf{3}^{\text {rd }}$ day & $\mathbf{4}^{\text {th }}$ day & $\mathbf{5}^{\text {th }}$ day & $\mathbf{6}^{\text {th }}$ day & $\mathbf{7}^{\text {th }}$ day & $\mathbf{8}^{\text {th }}$ day \\
\hline $9_{a}$ & 60 & 64 & 70 & 75 & 83 & 95 & - & - \\
\hline $9_{\mathrm{b}}$ & 57 & 62 & 69 & 73 & 82 & 93 & - & - \\
\hline $9_{c}$ & 54 & 57 & 63 & 73 & 80 & 86 & 97 & - \\
\hline $\mathbf{1 0}_{a}$ & 55 & 59 & 62 & 70 & 75 & 85 & 93 & - \\
\hline $\mathbf{1 0}_{\mathrm{b}}$ & 51 & 55 & 59 & 64 & 72 & 83 & 88 & 94 \\
\hline
\end{tabular}




\begin{tabular}{|c|c|c|c|c|c|c|c|c|}
\hline $10_{c}$ & 49 & 52 & 55 & 62 & 70 & 82 & 85 & 92 \\
\hline $11_{a}$ & 46 & 58 & 60 & 63 & 70 & 77 & 86 & 93 \\
\hline $11_{b}$ & 45 & 48 & 56 & 68 & 74 & 86 & 91 & 94 \\
\hline $11_{c}$ & 42 & 45 & 57 & 62 & 76 & 83 & 88 & 96 \\
\hline $12 a$ & 59 & 62 & 68 & 76 & 81 & 92 & - & - \\
\hline $12_{b}$ & 55 & 59 & 62 & 73 & 78 & 84 & 93 & - \\
\hline $12_{c}$ & 52 & 55 & 58 & 64 & 73 & 82 & 88 & 94 \\
\hline $13_{a}$ & 51 & 55 & 59 & 62 & 71 & 84 & 89 & - \\
\hline $13_{b}$ & 49 & 52 & 55 & 61 & 70 & 76 & 84 & 90 \\
\hline $13_{c}$ & 45 & 48 & 53 & 61 & 68 & 72 & 83 & 89 \\
\hline $14_{a}$ & 55 & 58 & 64 & 68 & 78 & 85 & 90 & - \\
\hline $14_{b}$ & 50 & 54 & 60 & 66 & 70 & 75 & 83 & 87 \\
\hline $14_{c}$ & 49 & 54 & 54 & 61 & 67 & 72 & 81 & 88 \\
\hline
\end{tabular}

Table(4)Antimicrobial activity of the synthesized anionic surfactants

\begin{tabular}{|c|c|c|c|c|c|c|c|c|}
\hline \multirow{2}{*}{ Surfactants } & \multicolumn{4}{|c|}{ Bacteria } & \multicolumn{4}{c|}{ Fungi } \\
\cline { 2 - 9 } & \multicolumn{2}{|c|}{ E. coli(G+) } & \multicolumn{2}{|c|}{$\begin{array}{c}\text { B. } \\
\text { megathorium(G }\end{array}$} & \multicolumn{2}{c|}{ A. flavus } & \multicolumn{2}{c|}{ Mucor Sp. } \\
\cline { 2 - 10 } & A & MIC & A & MIC & A & MIC & A & MIC \\
\hline $9_{\mathbf{a}}$ & +++ & 300 & + & 200 & ++ & ++ & ++ & 200 \\
\hline $9_{\mathrm{b}}$ & + & + & +++ & 100 & ++ & 200 & + & ++ \\
\hline $9_{\mathrm{c}}$ & + & 100 & ++ & 100 & + & + & ++ & ++ \\
\hline
\end{tabular}




\begin{tabular}{|c|c|c|c|c|c|c|c|c|}
\hline $10_{a}$ & + & 200 & ++ & 200 & + & ++ & ++ & + \\
\hline $10_{b}$ & -- & 100 & + & 300 & + & + & +++ & 200 \\
\hline $10_{c}$ & + & 200 & + & 200 & + & 300 & +++ & + \\
\hline $11_{a}$ & + & 100 & ++ & 100 & +++ & + & + & + \\
\hline $11_{b}$ & ++ & 200 & + & 100 & + & 200 & + & ++ \\
\hline $11_{c}$ & + & 300 & ++ & 200 & + & + & + & ++ \\
\hline $12 a$ & + & 200 & ++ & 300 & ++ & 200 & ++ & ++ \\
\hline $12_{b}$ & ++ & 200 & + & 300 & ++ & + & + & ++ \\
\hline $12_{c}$ & +++ & 100 & ++ & 100 & +++ & + & + & 100 \\
\hline $13_{a}$ & ++ & + & ++ & 100 & + & +++ & ++ & ++ \\
\hline $13_{b}$ & ++ & 100 & ++ & 100 & + & ++ & ++ & 200 \\
\hline $13_{c}$ & ++ & + & +++ & 100 & + & 100 & + & ++ \\
\hline $14_{a}$ & + & 200 & ++ & 200 & +++ & + & +++ & +++ \\
\hline $14_{b}$ & ++ & 100 & ++ & 100 & + & 200 & + & + \\
\hline $14_{c}$ & + & 300 & + & 100 & ++ & 100 & +++ & ++ \\
\hline
\end{tabular}

A=Antimicrobial activity of tested compounds, MIC $=$ Minimum inhibitory concentration, - inactive $+\geq 5 \mathrm{~mm}$, slightly active ++ $\geq 7 \mathrm{~mm}$, moderately active $+++\geq 10 \mathrm{~mm}$, highly active

\section{References}

1. Manal M.El.S, Alyaa A.S.S., Adel M. El.G., Abd El H. M. G, J.Surf. dete.,19: 137-144 (2016).

2. Linfield, W.M, Anionic Surfactants, pt. 1, Marce Dekker Inc., New York (1976).

3. Gawalek, G., Tenside, Akademie Uelag, Berlin(1975).

4. Linder,k.,Tenside,Textilhilfsmittel,Waschrohstoffe,Wissenschaftlie Verlagsgesellschaft $\mathrm{mbH}, \mathrm{Bd} 1$, Stuttgart(1964).

5. Schwartz A. M., Perry, J.W., Berch, J., Surface Active Agents and Detergents, Vol. 11, Interscience Publishers Inc., New York(1958).

6. Katritzky Comprehensive., Heterocyclic. Chem. Vol. 5 p. 56,233, 528 and 787(1984).

7. Allen,C. F. and Bell. A., Org. Synthesis, 26,11,(1946).

8. Townsend L. B., and Tipson, R. S., "Nucleic Acid Chemistry" Willey, New York. Part 2 and 1(1978).

9. Amine. M. S., Eissa, A.M.F., Shaaban, A. F., El-Sawy, A., and El-Sayed, R.I., Indian Journal of Chemistry Vo1. 37 B,pp. 1135-1156, 16 (1998).

10. Eissa A M F, M. El Hefnawy and M. Deef Allah, J Surfact Deterg , 16, 2, pp 161-171, 2013.

11. Findly A., Practical physical chemistry, $6^{\text {th }}$ edn. Longman, London, 1040-1069,1963.

12. Eissa AMF, EL-Hefnawy M, Bader S, Radwan M, Deef Allah M, Synthesis and characterization of anionic polymeric surfactants based on sulfonated styrene, J Surf Deterg, 15:411-418(2012).

13. El-Sukkary, M. M. A., El-Dib F., El-Sawy. A. A. and El-Ashry, S. H., Preparation of nonionic surfactants from rice bran oil,, Hungarian Journal of Industrial Chemistry, (14), 219 (1986). 
14. Draves,C.Z., J.Am.Dye Stuff Reporter,20,p.p 201,1941.

15. Eter, E.T., Richard, R.E. and Darid,A., Biodegradable surfactants starch,J.Am.Oil Chem.Soc.,51,p.p.486494,1974.

16. Eissa, A. M. F. , Grasas y Aceites., 58 (4) 379 (2007).

17. Eissa. A. M. F.; Olaj, Szappan, Kozmetika, 51 (4), 155 (2002).

18. Falbe J., Surfactants for Consumer, Chapter 4, Springer-Verlag, Heidelberg, 139-141(1986).

19. Leiferet C., S.Chidbouree, S.Hampson,S.workman, D.Sigee, H.A.Epton and .A.Harbour J.Appl.Bacterial.,78,97 ,1995.

20. Sageer Ahamad, Ghazala Imran, S. A. Ahmad and A. Hasnat oriental journal of chemistry, 2015, 31(2), 11691173

21. Pasee S, Cheerarot O, Baimark Y. Orient J Chem 2015; 31(3). 1551-1558

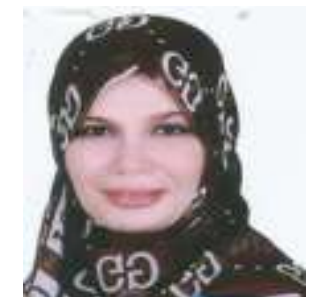

m.hasan@tu.edu.sa
Short Biography

Name: Magda Hassan Mostafa Abdel-Lattif

Age: 41

Mobile: +966554156900

Email: magdah11uk@hotmail.com

\section{Qualifications}

1. Bachelor of Science Chemistry - Department of Chemistry - Faculty of Science - Cairo University - 1997 is very good with honor

2. Master membership - Chemistry Faculty of Science, Department of Chemistry - University of Cairo in 2004

3. Ph.D. Philosophy of Science in Organic Chemistry - Chemistry Department, Faculty of Science - Cairo University 2008

4. professional doctorate in Accreditation of higher education institutions in the overall quality and organizational excellence light - International Arbitration Academy in collaboration with the Center for Community Service - Cairo University 2016

Positions

1- Associate professor of organic chemistry, Pharmaceutical chemistry section, deanship of Scientific research, Taif University, KSA

2- Consultant of Forensic Chemistry, Medico legal institute Egypt

Recent publications

1- Synthesis, reactions and pharmacological studies of new series of selenolo [2,3-b]tetrahydroquinoline, International Journal of Basic and Applied Sciences, 3 (4) (2014) 433-440

2- Microwave-Assisted Synthesis of New Series SomeAcetyl Coumarin Derivatives and Studying of Sometheir Pharmacological Activities, /J. Pharm. Sci. \& Res. Vol. 7(2), 2015, 83-88

3- New Methodology for Synthesis of Coumarin Derivatives as Potent Antimicrobial Agents, IJAPBC - Vol. 3(4), 2014

4- $\quad$ Efficient Microwave-Assisted Solvent-Free Synthesis and Molecular Docking Studies of 2-pyridone derivatives as Anticancer Agents and Evaluation of Cytotoxic Effects, JAC, vol.12(4), 2015

5- Synthesis of Some Novel Compounds of Saccharinyl Acetic Acid Containing Nucleus and Evaluation of Their Biological Activities as Antimicrobial,OJC , 2016, Vol. 32, No. (1): 567-574

6- $\quad$ Synthesis, Antiinflammatory, Analgesics, Molecular docking and ADMET studies of Diclofenyl Alanyl Hydrazide, JAAR, 2016, Vol(4)12, 1-10.

7- Synthesis of Anionic Surface Active Agents Containing Heterocyclic Moiety From Long Chain Fatty Alcohols, JAC, vol.2(1),2017

8- MIXED LIGAND-Co (II), Ni (II), Cu(II) AND Zr (IV) COMPLEXES AS ANTIMICROBIAL AND ANTIFUNGAL AGENTS; PREPARATION AND SPECTROSCOPIC STUDIES, journal Modern Chemistry \& Applications vol4(1), March 2017 